\title{
Introduction to the Symposium on Crime Without Fault
}

\author{
John Hasnas ${ }^{1}$
}

Published online: 30 May 2018

(C) Springer Science+Business Media B.V., part of Springer Nature 2018

Public Welfare Offenses are crimes that do not require mens rea. Originally limited to regulatory offenses that carried only small penalties, over the decades the scope of what falls within the ambit of such strict liability crimes has expanded. The Responsible Corporate Officer doctrine allows those who stand in a responsible relationship to a violation of law to be convicted for crimes committed by those they supervise. This form of vicarious criminal liability is not always limited to public welfare offenses and in some circuits supervisors can be convicted of crimes requiring mens rea that are committed by their subordinates.

In March of 2017, the Georgetown Institute for the Study of Markets and Ethics invited 11 of the nation's leading criminal law scholars to Georgetown Law School for a symposium on Crime Without Fault: The Justifiability of Public Welfare Offenses and the Responsible Corporate Officer Doctrine. The purpose of this symposium was to encourage some of the country's finest intellects to explore whether the introduction of crimes of strict and vicarious liability is theoretically consistent with the underlying purposes of the criminal law. The current issue of Criminal Law and Philosophy contains the results of that exploration.

The authors were given carte blanche to consider any aspect of the subject that they chose. Six of the authors-Leo Katz, Vera Bergelson, Gideon Yaffe, Paul Robinson, John Hasnas, and Kenneth Simons-directly considered the philosophical grounding for strict and vicarious liability crimes. Their contributions are presented in the section entitled, Arguments For and Against the Punishment of Public Welfare Offenses and the Responsible Corporate Officer Doctrine. Three of the authorsKimberly Ferzan, Samuel Buell, and Craig Lerner-examined the usefulness of the responsible corporate officer doctrine. Their contributions are presented in the section entitled, The Utility of the Responsible Corporate Officer Doctrine. And two

John Hasnas

hasnasj@georgetown.edu

1 Georgetown University, Washington, DC, USA 
of the authors-Michael Moore and Lawrence Alexander-elected to explore the general concept of strict liability. Their contributions are presented in the section entitled, Extrapolations and Larger Questions.

As the Executive Director of the Georgetown Institute for the Study of Markets and Ethics, it is my pleasure to offer this collection of articles to you as a repository of the latest and most sophisticated philosophical thinking on the subject of strict and vicarious criminal liability. 